\title{
Notes on the scythridid fauna of the Altai Mountains, with description of four new species (Lepidoptera: Scythrididae)
}

\author{
Kari Nupponen \& Timo Nupponen
}

Nupponen, K. \& Nupponen, T. 2001: Notes on the scythridid fauna of the Altai Mountains, with description of four new species (Lepidoptera: Scythrididae) — Entomol. Fennica 12: 81-93.

A list of 16 species embracing 393 specimens of the family Scythrididae collected during 23.VI.-11.VII.2000 from the Altai Mountains is presented. Four new species are described: Scythris cervella sp. n., S. hamatella sp. n., S. spinella sp. n. and S. tumidella sp. n. In addition, S. felixi Bengtsson \& Sutter, 1996 is reported as new for Russia and seven more species as new for the Altai region. The known distribution range of each species is given as well as further notes on some poorly known taxa.

Kari Nupponen, Miniatontie 1 B 9, FIN-02360 Espoo, Finland Timo Nupponen, Riilahdentie 5 D 15, FIN-02360 Espoo, Finland

Received 19 December 2000, accepted 31 January 2001

\section{Introduction}

The Altai Mountains are the westernmost and highest of the southern Siberian mountain ranges. They are located on the border zone of Russia, China and Mongolia, reaching $52^{\circ} \mathrm{N}$ in the north and $82^{\circ} \mathrm{E}$ in the west, and continuing over $1000 \mathrm{~km}$ to the southeast in Mongolia. The highest peak in the Altai, $4506 \mathrm{~m}$ a.s.l., lies on the border line of Russia and China. The majority of the habitats in the Altai are conifer forests. Different kinds of steppes and meadows are present in the river valleys, and alpine meadows and mountain tundra exist locally at high altitudes over $2300 \mathrm{~m}$. At the highest elevations (over $3500 \mathrm{~m}$ ) the ground is covered by glaciers.

The scythridid fauna of the Altai Mountains is poorly known. Sinev (1993) published a list comprising eight species recorded during a Finnish-Russian expedition to southwestern Altai in 1983. It is the only publication available concerning the scythridid fauna of the Altai range. However, some new taxa of scythridids have subse- quently been described from the neighbouring areas, such as the Republic of Tuva (Bengtsson, 1997a), Mongolia (Bengtsson \& Sutter 1996) and the Baikal region (Bengtsson \& Liška 1996).

The present article is based on material collected by the authors during 23.VI.-11.VII.2000 in the southeastern part of the Russian Altai, mainly in the valley of the river Chuja and adjacent mountains. Despite rainy weather, altogether 393 specimens of scythridids belonging to 16 species were collected. In addition, more than 100 specimens were observed but not collected, because they were easily determined in the field. Four of the species are previously unknown, and they are described in this paper. The type specimens can be loaned by request through the Finnish Museum of Natural History, University of Helsinki or directly from the authors.

\section{List of scythridid species}

The species are presented in alphabetic order, as 


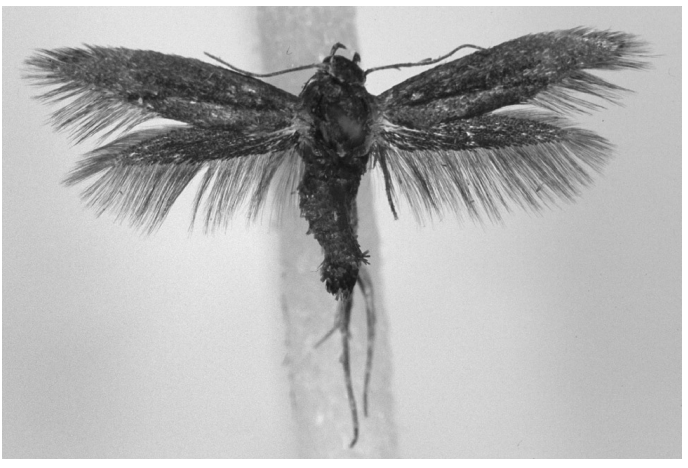

Fig. 1. Imago of Scythris braschiella (Hofmann, 1898).

the family Scythrididae has not been revised earlier and the relationships within the family are not fully understood. The grouping of the species inside the genus follows that of Bengtsson (1997). The known distribution for each species is given, as well as further notes on some poorly known taxa.

\section{Scythris acipenserella K. \& T. Nupponen, 2000}

Russia, Altai Mountains, $50^{\circ} 14-16^{\prime} \mathrm{N} 87^{\circ} 50-55^{\prime} \mathrm{E}, 1500-$ 1700 m, Kuraiskaja step, 26.VI.2000, 1 o", T. \& K. Nupponen leg.

Distribution. Russia (S Ural), S Spain.

Remarks. This record extends the known distribution of the species $2000 \mathrm{~km}$ to the east. New to the Altai region.

\section{Scythris baikalensis Bengtsson \& Liška, 1996}

Russia, Altai Mountains, $50^{\circ} 16-20^{\prime} \mathrm{N} 87^{\circ} 50-55^{\prime} \mathrm{E}, 2000$ 2500 m, Kuraisky hrebet, 18 0'0", 18 우우 26.VI.2000, 13 రొరౌ', 6 우 27.VI.2000, 1 O’ 04.VII.2000 T. \& K. Nupponen leg.

Russia, Altai Mountains, $50^{\circ} 14-16^{\prime} \mathrm{N} 87^{\circ} 50-55^{\prime} \mathrm{E}$,

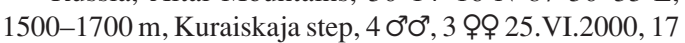

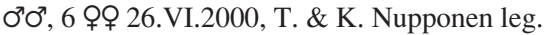

Distribution. Russia (Republic of Tuva, Krasnojarskij kraj, Baikal region).

Remarks. The species was abundant on hot, rocky slopes. These records are the westernmost ones known. New to the Altai region.

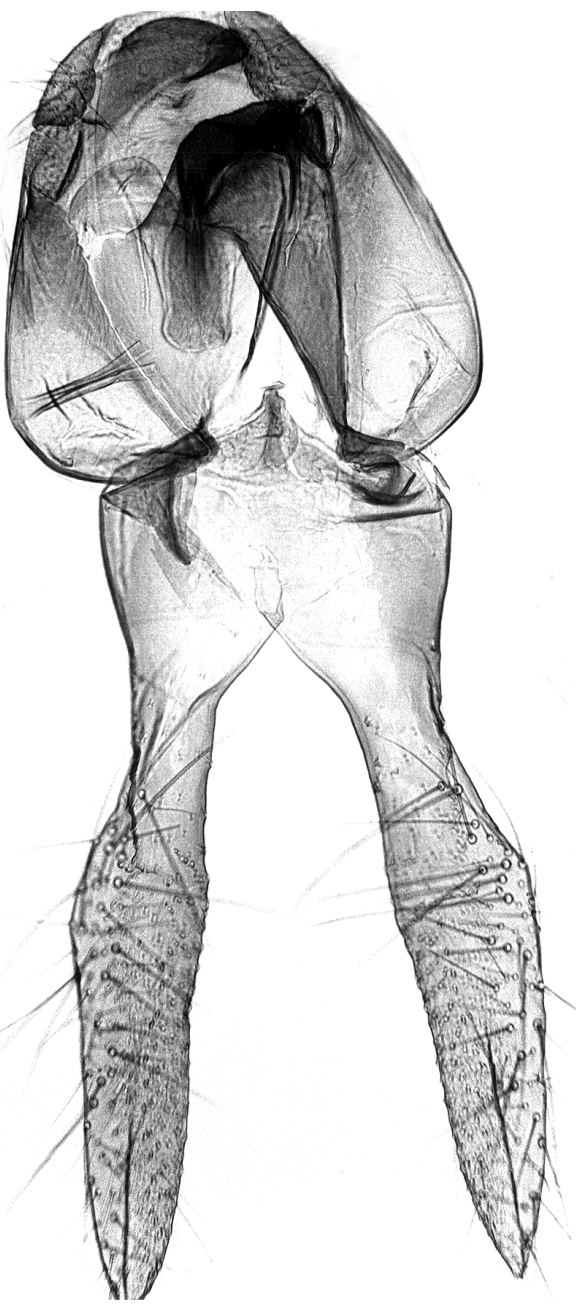

Fig. 2. Male genitalia of Scythris braschiella.

\section{Scythris bifissella (Hofmann, 1889)}

Russia, Altai Mountains, 50¹4-16N 8740E, 1500 m, Chuja valley, Aktash village $5 \mathrm{~km} \mathrm{SE}, 10^{\circ}, 2$ 우 05.VII.2000, T. \& K. Nupponen leg.

Russia, Altai Mountains, 50 ${ }^{\circ} 16-20^{\prime} \mathrm{N} 87^{\circ} 50-55^{\prime} \mathrm{E}$,

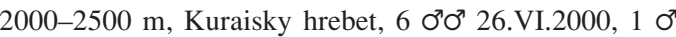
28.VI.2000, 1 ㅇ 30.VI.2000, T. \& K. Nupponen leg.

Russia, Altai Mountains, 50 ${ }^{\circ} 14-16^{\prime} \mathrm{N} 87^{\circ} 50-55^{\prime} \mathrm{E}$, 1500-1700 m, Kuraiskaja step, 4 ơ ơ, 1 ㅇ 25.VI.2000, 1 우 26.VI.2000, 1 ㅇ 05.VII.2000, T. \& K. Nupponen leg.

Distribution. C Europe, Russia (Baikal region, Altai Mountains, S Ural). 


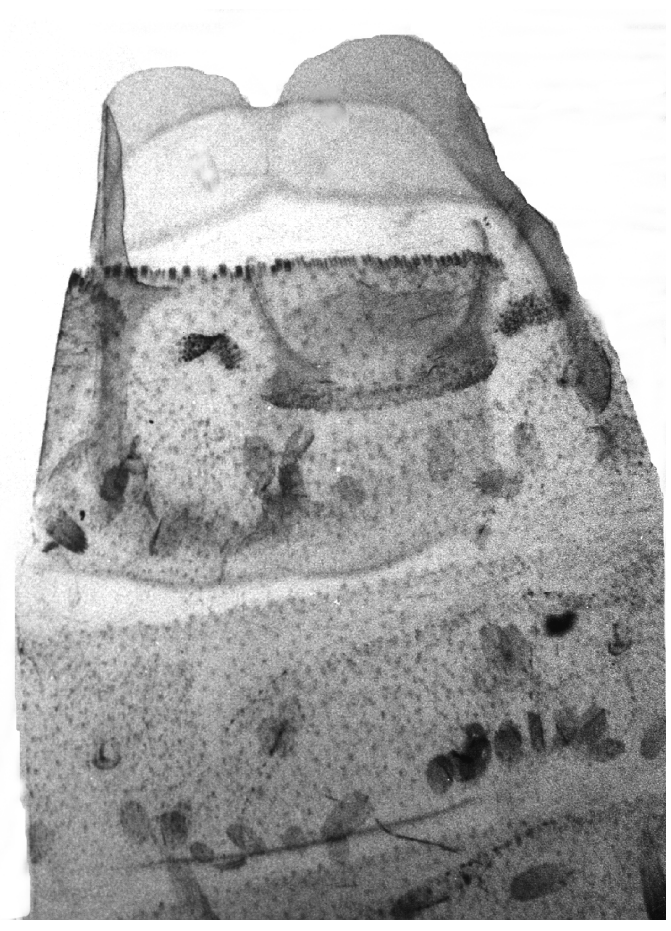

Fig. 3. Tergum VIII (down) and sternum VIII (up at middle) of Scythris braschiella.

\section{Scythris braschiella (Hofmann, 1898)}

Russia, Altai Mountains, $50^{\circ} 25^{\prime} \mathrm{N} 86^{\circ} 35-40^{\prime} \mathrm{E}, 800 \mathrm{~m}$, Katun valley near Inja village, 07.VII.2000, T. \& K. Nupponen leg. (Fig. 1). Genitalia slide: K. Nupponen prep. no. $4 / 09 . X I .2000$.

Distribution. Germany, Greece, Turkey, Poland, Russia (S Ural).

Remarks. There are some details in the Altaian specimen which do not exactly coincide with typical braschiella: In the male genitalia the basal fusion of valvae is rather large (Fig. 2) and the posterior margin of tergum VIII is wider with a very deep medial incision (Fig. 3). The moth is also larger in size (wingspan $11.5 \mathrm{~mm}$ ) and more robust in appearance than a typical braschiella. However, there is some variation in the genitalia of braschiella and extreme forms are very similar to the Altaian specimen. More material from the Altai region is needed to study the variation of the differing details more closely. With some

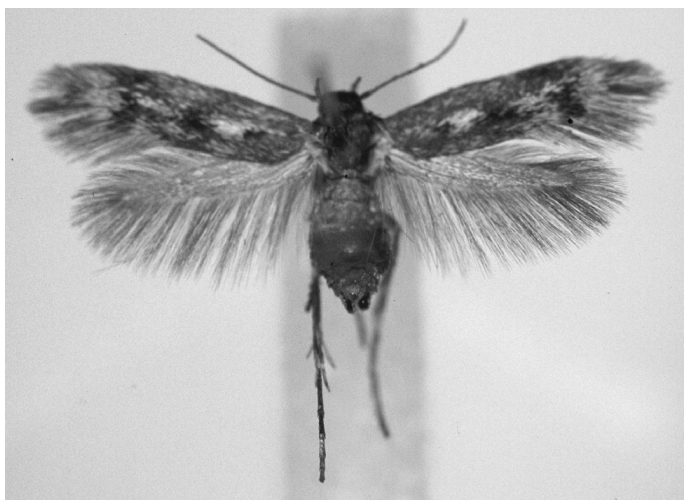

Fig. 4. Imago (holotype) of Scythris cervella sp. n.

doubt, we regard our specimen to be braschiella for the moment. This record extends the known distribution range of braschiella $2000 \mathrm{~km}$ to the east. New to the Altai region.

\section{Scythris cervella sp. $\mathrm{n}$.}

Type material. Holotype: $0^{7}$ (Fig. 4): Russia, Altai Mountains, $50^{\circ} 16-20^{\prime} \mathrm{N} 87^{\circ} 50-55^{\prime} \mathrm{E}, 2000-$ 2500 m, Kuraisky hrebet, 27.VI.2000, T. \& K. Nupponen leg. In coll. T. \& K. Nupponen.

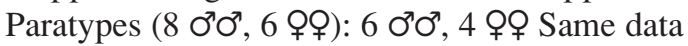
as holotype. Russia, Altai Mountains, 50 $14-16^{\prime} \mathrm{N}$ 87 $50-55^{\prime}$ E, 1500-1700 m, Kuraiskaja step, $10^{\circ}$ 05.VII.2000, 1 ㅇ 13.VII.2001, T. \& K. Nupponen leg. $10^{7}, 1$ Q Russia, Altai Mountains, 1400-1500 $\mathrm{m}, 51^{\circ} 00-10^{\prime} \mathrm{N} 85^{\circ} 35-45^{\prime} \mathrm{E}$, Sarlyk region, 25.VI.2000, T. \& K. Nupponen leg. Genitalia slides: K. Nupponen prep. no. 5/07.XI.2000 (O'), 4/07.XI.2000 (O). Three further genitalia preparations preserved in glycerol. Paratypes in the collections of T. \& K. Nupponen and Bengt $\AA$. Bengtsson.

Diagnosis. Externally S. cervella sp. n. is rather easy to separate from other scythridids of equal size by its mottled and moderately broad forewings. Worn specimens appear to be more unicoloured, because white scales are chafed away first. In the male genitalia, the characteristic details separating $S$. cervella from closely related 


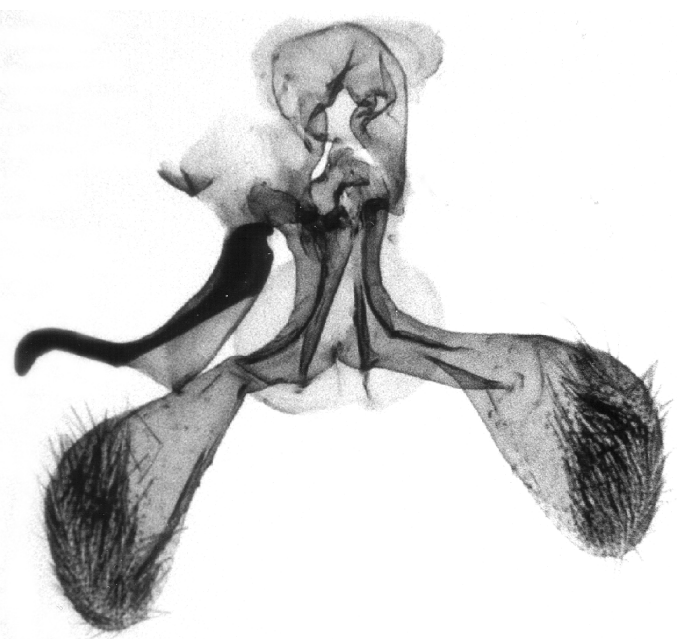

Fig. 5. Male genitalia of Scythris cervella sp. n. (paratype).

species (see Remarks) are the lateral processes of tergum VIII being bifurcate and strongly sclerotized on both sides, as well as the shape of gnathos. In addition, the spatulate portion of the valvae is broader and a little bit shorter in cervella than in its close relatives. The structure of the female genitalia resembles that of many eastern Palaearctic scythridids. The main characteristics of cervella are sterigma with incised anterior margin and a broad, anteriorly convex sclerotized tip without transparent cylindrical distal portion, and the posterior margin of sternum VII being rather strongly extended and medially deeply incised with labiate sclerotization (cf. S. albisaxella K. \& T. Nupponen, 2000, S. ammobia Falkovitch, 1972, S. hamatella sp. n., S. kullbergi Bengtsson, 1997 and S. terekholensis Bengtsson, 1997).

Description. Wingspan 8-9 mm. Head, antenna, collar, tegula, neck tuft and thorax dark brown. Haustellum dark brown, mixed with greyish white scales. Labial palp: segment I beige, segment II and segment III dark brown, basally and on upper surface mixed with greyish white scales. Legs brown with scattered dirty beige and greyish white scales occurring more frequently on femur. Abdomen in male fuscous, ventrally mixed with dirty beige scales, anal tuft paler; in female dorsally dark fuscous with scattered pale brown scales, ventrally dirty beige. Forewing dark brown; moderately distinct pale brown tornal spot and subapical fascia, and same coloured scattered scales in costal area and in basal half of dorsal margin; in fold distinct whitish spot at $1 / 4$ and two more or less indistinct spots of same colour at base and at cell end. Hindwing fuscous, darker in female.

Male genitalia (Figs. 5-6). Uncus reduced. Gnathos sclerotized, slightly asymmetrical; basal half ventrally extended; terminal half thin, distally bent and bluntly pointed. Aedeagus short and thick, distally curved and tapered. Valvae basally fused, then with narrow shaft; apical 2/3 large, spatular, setose process with straight ventral margin, convex dorsal margin and rounded apex. Sternum VIII rectangular, posterior margin shallowly concave. Tergum VIII subtriangular; anterior margin medially incised; medioposterior margin with two digitate extensions; both lateral processes long and robust, distally bifurcate and sclerotized.

Female genitalia (Fig. 7). Sterigma triangular, anterior margin with $\mathrm{V}$-shaped incision; tip strongly sclerotized, anterior margin of sclerotized part convex. Sternum VII quadrangular; posterior margin extended with deep $U$-shaped medial incision and small labiate sclerotization at 'bottom' of incision. Apophyses anteriores $0.4 \times$ length of apophyses posteriores.

Bionomy. The specimens were collected in late June and early July on rocky steppe slopes with Artemisia sp. as a dominant plant. The biology is unknown.

Distribution. Russia (Altai Mountains). The species is known from Kurai region in Chuja valley and from Sarlyk region in Katun valley.

Etymology. Lat. cervus = deer. From two lateral processes of tergum VIII in the male genitalia, resembling legs of a deer.

Remarks. There are several small, eastern scythridids having similar structure in the genitalia as $S$. cervella sp. n. (S. albisaxella K. \& T. Nupponen, 2000, S. arkaimensis Bengtsson, 2000, S. hamatella sp.n. and S. terekholensis Bengtsson, 1997, possibly also $S$. kullbergi Bengtsson, 1997). Such characteristics are in the male genitalia an asymmetrical, strongly sclerotized gnathos, basally fused more or less spatulate valvae and usually sclerotized processes of tergum VIII, and in the female genitalia a triangular, distally sclerotized 
Fig. 6. Tergum VIII (right) and sternum VIII (left) of Scythris cervella sp. $\mathrm{n}$. (paratype).
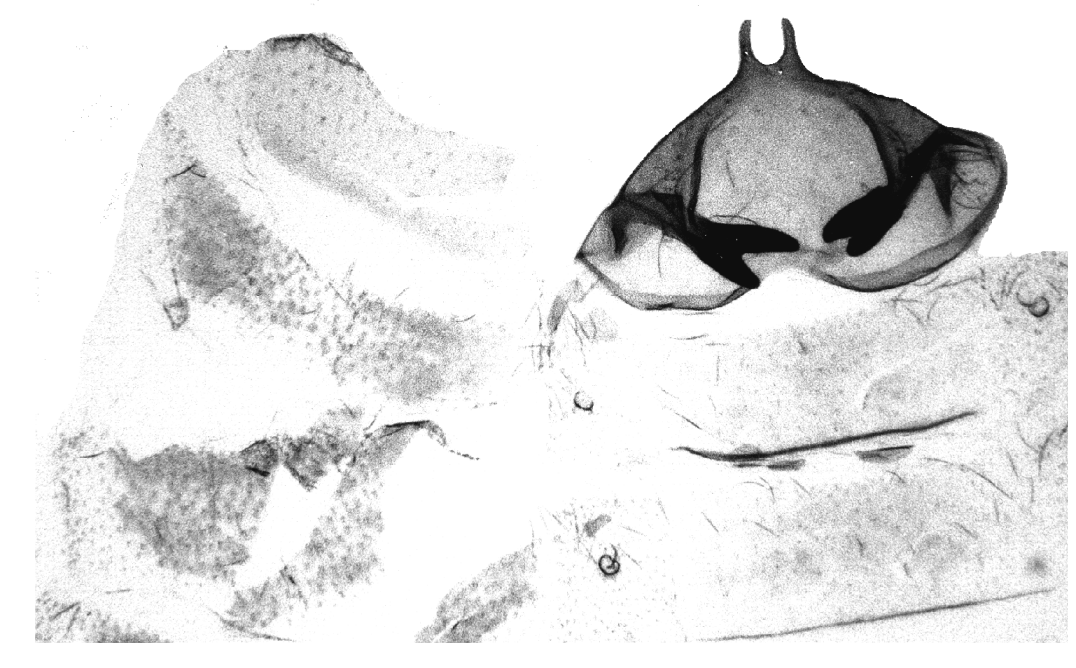

sterigma and the structure of the posterior margin of sternum VII (see Diagnosis). S. cervella sp. n. belongs to this species-group.

\section{Scythris felixi Bengtsson \& Sutter, 1996}

Russia, Altai Mountains, 50³5-40`N 86²0-30’E, 700800 m, near Kupchegen village, $10^{7}$ 07.VII.2000, T. \& K. Nupponen leg.

Russia, Altai Mountains, 50 $0^{\circ} 16-20^{\prime} \mathrm{N} 87^{\circ} 50-55^{\prime} \mathrm{E}$ 2000-2500 m, Kuraisky hrebet, 3 ơ $^{7}$ 27.VI.2000, T. \& K. Nupponen leg.

Distribution. Mongolia (Mörön).

Remarks. The species was previously known only by the type series. New to Russia.

\section{Scythris flaviventrella (Herrich-Schäffer, 1855)}

Russia, Altai Mountains, $50^{\circ} 14-16^{\prime} \mathrm{N} 87^{\circ} 40^{\prime} \mathrm{E}, 1500 \mathrm{~m}$, Chuja valley, Aktash village $5 \mathrm{~km} \mathrm{SE}, 10^{7} 05$.VII.2000, T. \& K. Nupponen leg.

Russia, Altai Mountains, 50³5-40`N 86²0-30`E, 700-800 m, near Kupchegen village, $10^{7}$ 07.VII.2000, T. \& K. Nupponen leg.

Distribution. C and S Europe, Turkey, Russia (S Ural).

Remarks. These records extend the known distribution of the species $2000 \mathrm{~km}$ to the east. New to the Altai region.

\section{Scythris gozmanyi Passerin d'Entrèves, 1986}

Russia, Altai Mountains, 50²5N 86³5-40`E, 800 m, Katun valley near Inja village, $10^{\prime}, 1$ 우 07.VII.2000, T. \& K. Nupponen leg.

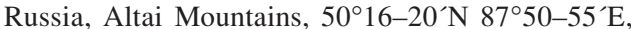
2000-2500 m, Kuraisky hrebet, 3 우 27.VI.2000, 1 o', 1 ㅇ 28.VI.2000, T. \& K. Nupponen leg.

Russia, Altai Mountains, 50 $0^{\circ} 14-16^{\prime} \mathrm{N} 87^{\circ} 50-55^{\prime} \mathrm{E}$, 1500-1700 m, Kuraiskaja step, 4 ơ $0^{\prime}, 3$ 우우 26.VI.2000, 3 ơơ 05.VII.2000, T. \& K. Nupponen leg.

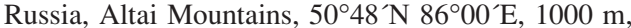
near Shashikman village, 1 0 08.VII.2000, T. \& K. Nupponen leg.

Distribution. Russia (S Ural), Hungary, Poland.

Remarks. The species occurs everywhere in dry Artemisia-steppes. These records extend the known distribution of the species $2000 \mathrm{~km}$ to the east. New to the Altai region.

\section{Scythris hamatella sp. n.}

Type material. Holotype: $0^{7}$ (Fig. 8): Russia, Altai Mountains, $50^{\circ} 14-16^{\prime} \mathrm{N} 87^{\circ} 50-55^{\prime} \mathrm{E}, 1500-$ 1700 m, Kuraiskaja step, 26.VI.2000, T. \& K. Nupponen leg. Genitalia slide: K. Nupponen prep. no. 1/07.XI.2000. In coll. T. \& K. Nupponen.

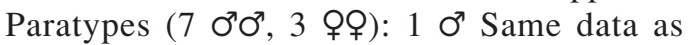
holotype. Russia, Altai Mountains, 50¹6-20`N 


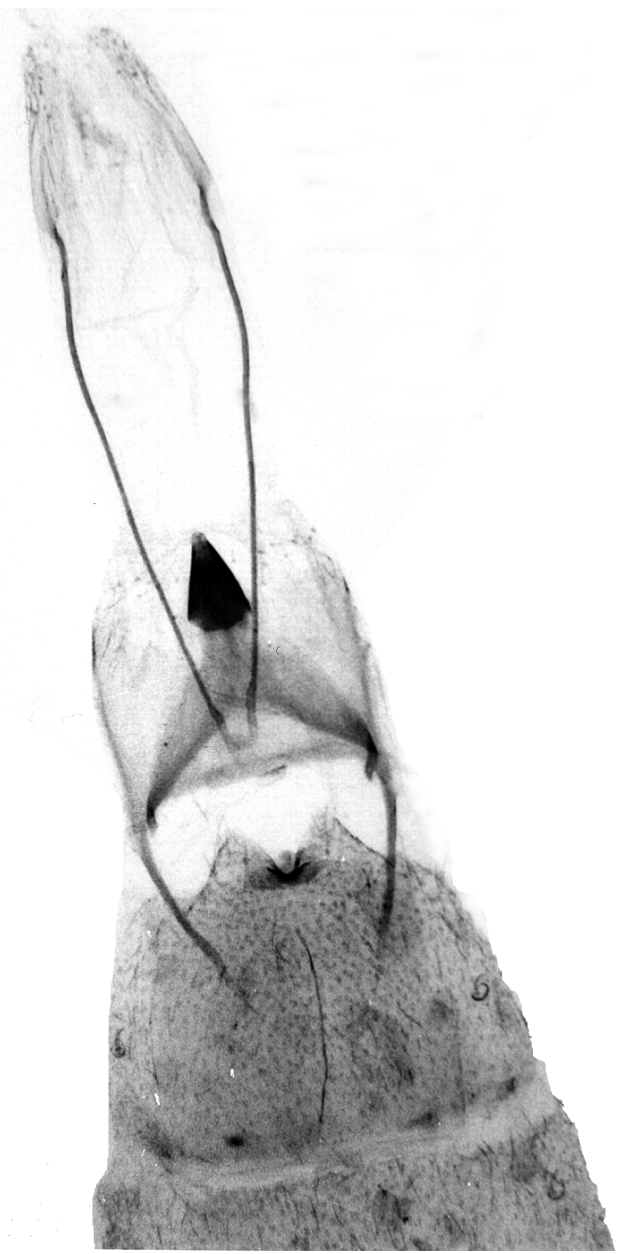

Fig. 7. Female genitalia of Scythris cervella sp. n. (paratype).

87 $50-55^{\prime}$ E, 2000-2500 m, Kuraisky hrebet, 1 ㅇ 27.VI.2000, 1 O' 13.VII.2001, T. \& K. Nupponen

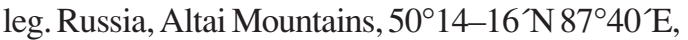
$1500 \mathrm{~m}$, Chuja valley, Aktash village $5 \mathrm{~km} \mathrm{SE}, 1$

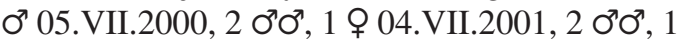
ㅇ 14.VII.2001, T. \& K. Nupponen leg. Genitalia slide: K. Nupponen prep. no. 1/09.XI.2000 (O). Three further genitalia preparations preserved in glycerol. All paratypes in coll. T. \& K. Nupponen.

Diagnosis. Externally S. hamatella sp. n. may be confused with many other small, dark scythridids, for example S. felixi Bengtsson \& Sutter, 1996, S. gozmanyi Passerin d'Entrèves, 1986 and S. arkaimensis Bengtsson, 2000. The long and narrow forewings may help to identify the moth. In

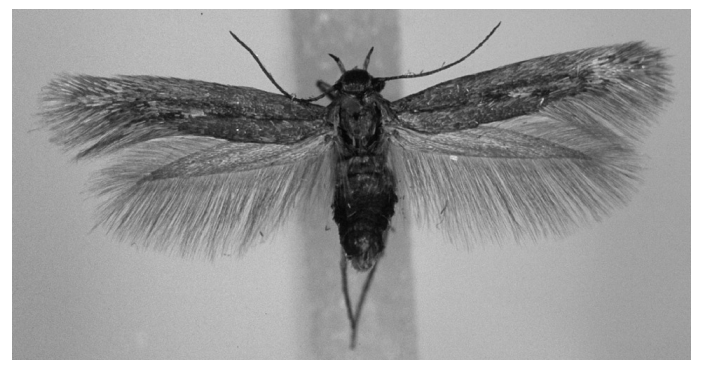

Fig. 8. Imago (holotype) of Scythris hamatella sp. n.

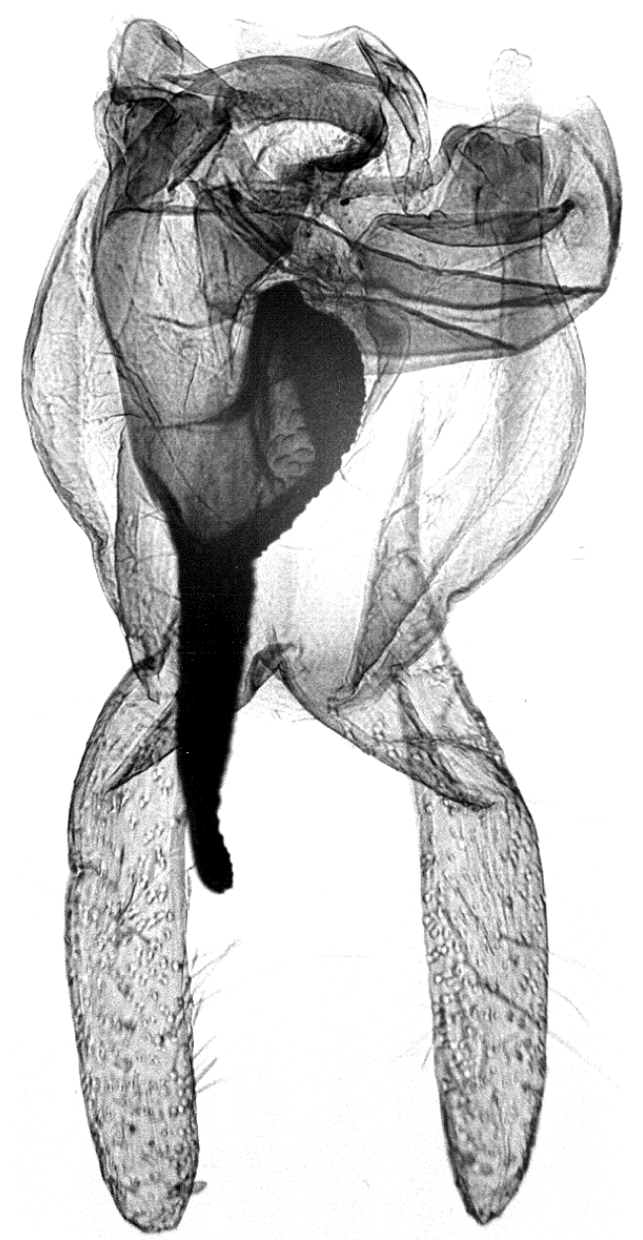

Fig. 9. Male genitalia of Scythris hamatella sp. n. (holotype).

tergum VIII of the male genitalia, the sclerotized lateral process is hooked, lateral margins with rounded extension and medioposterior process is thick with rounded tip. The valvae are not spatu- 
Fig. 10. Tergum VIII (left) and sternum VIII (right) of Scythris hamatella sp. $\mathrm{n}$. (holotype).

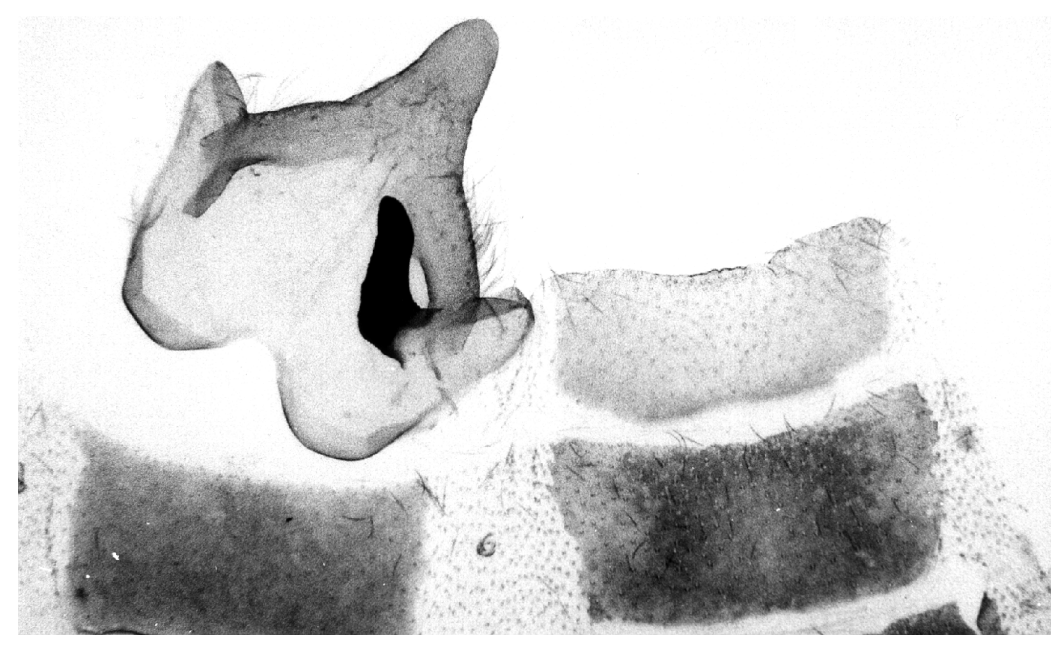

late as in closely related taxa (see Remarks of $S$. cervella sp. $\mathrm{n}$. above). In the female genitalia, the sclerotized tip of sterigma is narrow (cf. $S$. kullbergi, S. ammobia, S. cervella, S. terekholensis) and transparent distal portion long and narrow (cf. S. cervella, S. albisaxella, S. terekholensis). Sternum VII is more elongate than that of the related species and the posterior margin of it only slightly concave without medial incision and labiate process.

Description. Wingspan 10-11 mm. Head, thorax, collar, tegula, antenna, neck tuft and haustellum dark brown, haustellum and ventral side of scape with a few dirty beige scales. Labial palp: segment I dirty beige; segment II and segment III dark brown, segment II and basal half of segment III mixed with dirty beige scales. Legs: femur dirty beige; tibia and tarsus dark brown, mixed with pale brown and a few dirty beige scales. Abdomen fuscous, ventrally more (in male) or less (in female) mixed with whitish grey. Forewing long and narrow, dark brown, apical 1/4 with scattered paler brown scales; in fold small dirty whitish spot at midwing. Hindwing fuscous.

Male genitalia (Figs. 9-10). Uncus reduced. Gnathos asymmetrical, long and sclerotized; basal $1 / 3$ wide, distal 2/3 narrow, slightly bent; sclerotized part shallowly furrowed. Aedeagus short and thick, straight, distally tapered. Valvae basally fused, rather long, slightly bent, of equal width, setose. Sternum VIII rectangular, $2.5 \times$ as wide as high. Tergum VIII subtriangular, terminal part more sclerotized, medioposterior process thick with rounded tip; anterior margin incised; lateral margins medially with roundish extension; lateral processes thick, long one strongly sclerotized, hooked, subapically with small extension.

Female genitalia (Fig. 11). Sterigma triangular, posteriorly strongly sclerotized, tip semi-transparent and blunt. Sternum VII rectangular, longish, posteriorly shallowly concave. Apophyses anteriores $1 / 3$ length of apophyses posteriores.

Bionomy. The specimens were collected in late June and early July on dry Artemisia-steppes. The biology is unknown.

Distribution. Russia (Altai Mountains). The species is known from Aktash-Kurai region from two different places located close to each other.

Etymology. Lat. hamatus $=$ hooked. From a hooked, sclerotized lateral process of tergum VIII in the male genitalia.

Remarks. S. hamatella sp. n. belongs to the same species-group as $S$. cervella sp. n. (see Remarks of $S$. cervella above).

\section{Scythris karinupponeni Bengtsson, 2000}

Russia, Altai Mountains, $50^{\circ} 14-16^{\prime} \mathrm{N} 87^{\circ} 40^{\prime} \mathrm{E}, 1500 \mathrm{~m}$, Chuja valley, Aktash village $5 \mathrm{~km} \mathrm{SE}, 460^{7} 0^{7}, 5$ 우우

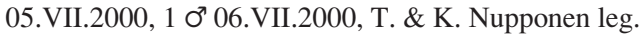

Russia, Altai Mountains, $50^{\circ} 18-20^{\prime} \mathrm{N} 87^{\circ} 30-40^{\prime} \mathrm{E}$, $1400-1500 \mathrm{~m}$, Chuja valley near Aktash village, 5 o $^{7} \mathrm{O}^{\prime}, 3$ 우 06.VII.2000, T. \& K. Nupponen leg.

Russia, Altai Mountains, $50^{\circ} 25^{`} \mathrm{~N} 86^{\circ} 35-40^{`} \mathrm{E}, 800 \mathrm{~m}$, Katun valley near Inja village, $80^{7} 0^{7} 07$.VII.2000, T. \& K. Nupponen leg. 


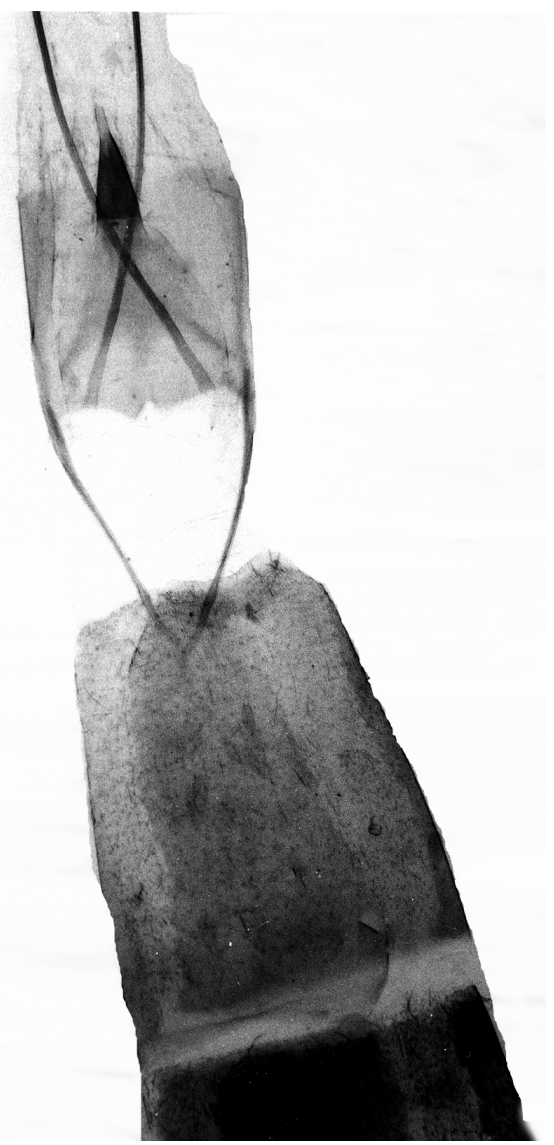

Fig. 11. Female genitalia of Scythris hamatella sp. $n$. (paratype).

Russia, Altai Mountains, $50^{\circ} 48^{`} \mathrm{~N} 86^{\circ} 00^{`} \mathrm{E}, 1000 \mathrm{~m}$, near Shashikman village, $20^{7} 0^{7} 08$.VII.2000, T. \& K. Nupponen leg.

Distribution. Russia (S Ural, Magadan oblast).

Remarks. S. karinupponeni Bengtsson, 2000 was previously known only by the type series from the southern Ural Mountains and Magadan region. The species is locally common in dry steppe habitats. New to the Altai region.

\section{Scythris mikkolai Sinev, 1993}

Russia, Altai Mountains, 50 $14-16^{\prime} \mathrm{N} 87^{\circ} 40^{\prime} \mathrm{E}, 1500 \mathrm{~m}$, Chuja valley, Aktash village $5 \mathrm{~km} \mathrm{SE}, 10^{7} 05$.VII.2000, 1 O’ 06.VII.2000, T. \& K. Nupponen leg.

Russia, Altai Mountains, $50^{\circ} 16-20^{\prime} \mathrm{N} 87^{\circ} 50-55^{\prime} \mathrm{E}$, 2000-2500 m, Kuraisky hrebet, 1 O' 02.VII.2000, T. \& K. Nupponen leg.

Distribution. Russia (Primoriye, S Siberia, S Ural, Samara region).

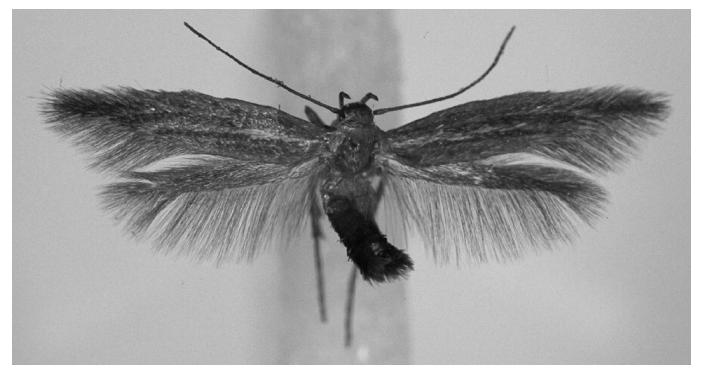

Fig. 12. Imago (holotype) of Scythris spinella sp. n.

\section{Scythris obscurella (Scopoli, 1763)}

Russia, Altai Mountains, 50 $14-16^{`} \mathrm{~N} 87^{\circ} 40^{`} \mathrm{E}, 1500 \mathrm{~m}$, Chuja valley, Aktash village $5 \mathrm{~km} \mathrm{SE}, 2$ O’ $^{7} 25$.VI.2000, T. \& K. Nupponen leg.

Russia, Altai Mountains, $50^{\circ} 16-20^{\prime} \mathrm{N} 87^{\circ} 50-55^{\prime} \mathrm{E}$, 2000-2500 m, Kuraisky hrebet, 17 ○రా, 14 우 26.VI.2000,

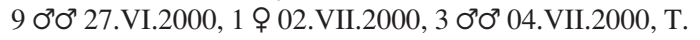
$\&$ K. Nupponen leg.

Russia, Altai Mountains, $51^{\circ} 35^{\prime} \mathrm{N} 85^{\circ} 55^{\prime} \mathrm{E}, 700 \mathrm{~m}$, Katun valley, Ust-Sema village $10 \mathrm{~km} \mathrm{SE,} 10^{7}, 1$ 우 23.VI.2000, T. \& K. Nupponen leg.

Distribution. C and S Europe, Russia (Baikal region, Altai Mountains, $\mathrm{S}$ Ural).

Remarks. The species is abundant in alpine meadows at higher altitudes (over $2000 \mathrm{~m}$ ).

\section{Scythris remexella K. Nupponen \& Kaitila, 2000}

Russia, Altai Mountains, $50^{\circ} 18-20^{\prime} \mathrm{N} 87^{\circ} 30-40^{`} \mathrm{E}, 1400-$ $1500 \mathrm{~m}$, Chuja valley near Aktash village, $1 \mathrm{O}^{7}$ 06.VII.2000, T. \& K. Nupponen leg.

Distribution. Russia (S Ural).

Remarks. The species was previously known only by the type series from the southern Ural Mountains. However, the occurrence of $S$. remexella further in the east was expected (see K. Nupponen et al. 2000). This record extends the known distribution of the species $2000 \mathrm{~km}$ to the east. New to the Altai region.

Scythris sinensis (Felder \& Rogenhofer, 1775)

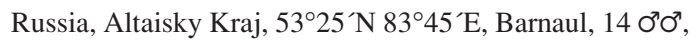
12 우우 23.VI.2000, 3 0"0", 7 우우 11.VII.2000, T. \& K. Nupponen leg.

Distribution. Transpalaearctic. 
Fig. 13. Male genitalia of Scythris spinella sp. $\mathrm{n}$. (holotype).

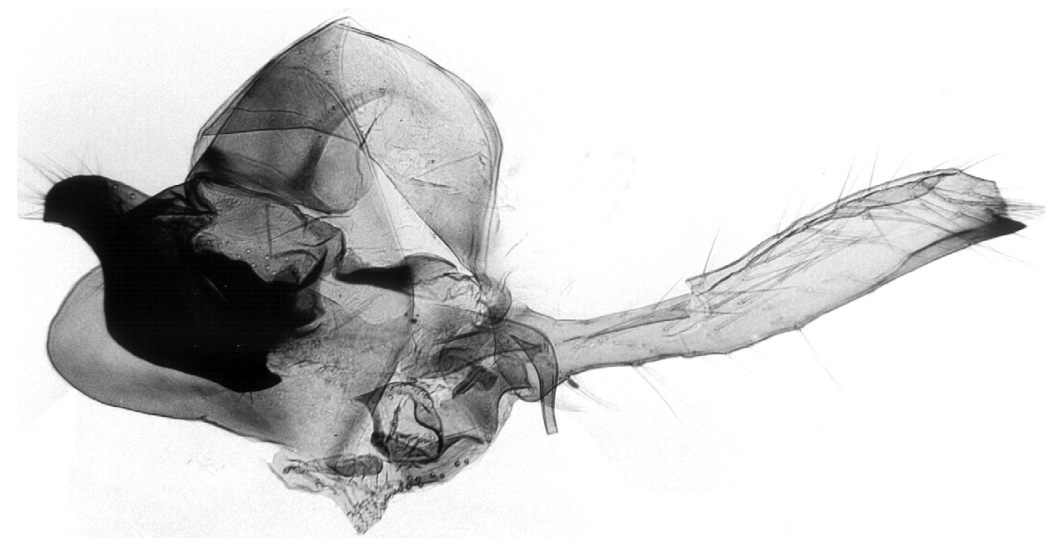

Remarks. The species was common in the center of Barnaul city. The specimens seem to prefer such spots where the host plant (Chenopodium) is growing close to warm walls.

\section{Scythris spinella sp. n.}

Type material. Holotype: $0^{7}$ (Fig. 12): Russia, Altai Mountains, $50^{\circ} 14-16^{\prime} \mathrm{N} 87^{\circ} 50-55^{\prime} \mathrm{E}, 1500-$ 1700 m, Kuraiskaja step, 26.VI.2000, T. \& K. Nupponen leg. Genitalia slide: K. Nupponen prep. no. 3/09.XI.2000. In coll. T. \& K. Nupponen. Paratypes ( $30^{7} 0^{\prime \prime}, 1$ O $)$ : 1 ㅇ Same data as holotype. Russia, Altai Mountains, 50 $16-20^{\prime}$ N 87 $50-55^{\prime} \mathrm{E}$, 2300 m, Kuraisky hrebet, 2 O'ర $^{7} 10$. VII.2001, $10^{7}$ 11.VII.2001, K. Nupponen leg. Genitalia slide: K. Nupponen prep. no. 2/09.XI.2000. In coll. T. \& K. Nupponen.

Diagnosis. Externally S. spinella sp. n. may be confused with several other small, dark scythridids, especially S. luxatiella K. Nupponen \& Kaitila, 2000 and S. penicillata Chrétien, 1900. S. spinella differs from both of them by the more purplish lustre of the forewing. S. luxatiella has longer antennae and less convex costal margin of the forewing. In S. penicillata the streak in fold of the forewing is paler, broader and longer, and scattered whitish scales exist also in the apical part of the forewing. The male genitalia structure of $S$. spinella is very similar to that of $S$. penicillata. The main characters distinguishing spinella are a thorn-like extension in the apex of right valva and the shape of gnathos with thick, pointed basal extension, as well as more symmetrical segment
VIII. The female genitalia of S. spinella are almost identical to those of penicillata, ventral plate of segment VIII being slightly narrower and strongly sclerotized portion of sterigma slightly shorter.

Description. Wingspan 9.5-10 mm. Head, thorax, collar, antenna, tegula and legs dark brown, neck tufts slightly paler. Haustellum dark brown, mixed with few pale fuscous scales. Antenna $0.8 \times$ length of forewing. Labial palp: segment I and basal half of segment II brown; distal half of segment II dark brown; segment III fuscous, paler than distal half of segment II but darker than segment I. Abdomen dorsally dark fuscous, ventrally in female slightly paler, in male with scattered pale brown scales. Forewing dark brown with faint purplish lustre; in fold more or less indistinct pale yellowish brown (in male) or yellowish fuscous (in female) streak from base to midwing; costal margin slightly convex. Hindwing dark fuscous.

Male genitalia (Figs. 13-14). Uncus asymmetrical, sclerotized, bifurcate, tips more or less pointed. Gnathos strongly asymmetrical, sclerotized, with thick, bent and pointed, setose basal extension; medial part broad, terminal tip pointed. Tegumen hood-shaped; on both lateral margins narrow, sclerotized basal extension. Aedeagus 1/3 length of right valva, tapered, at middle curved $80^{\circ}$. Right valva long and slender, cut off and setose; ventral margin distally with thorn-like extension; both dorsal and ventral margin with narrow flap at distal 1/4. Left valva short and broad, without extensions, distal margin rounded. Tergum VIII rectangular, $3 \times$ as wide as high. Sternum VIII rectangular, narrow, more or less membranous. 

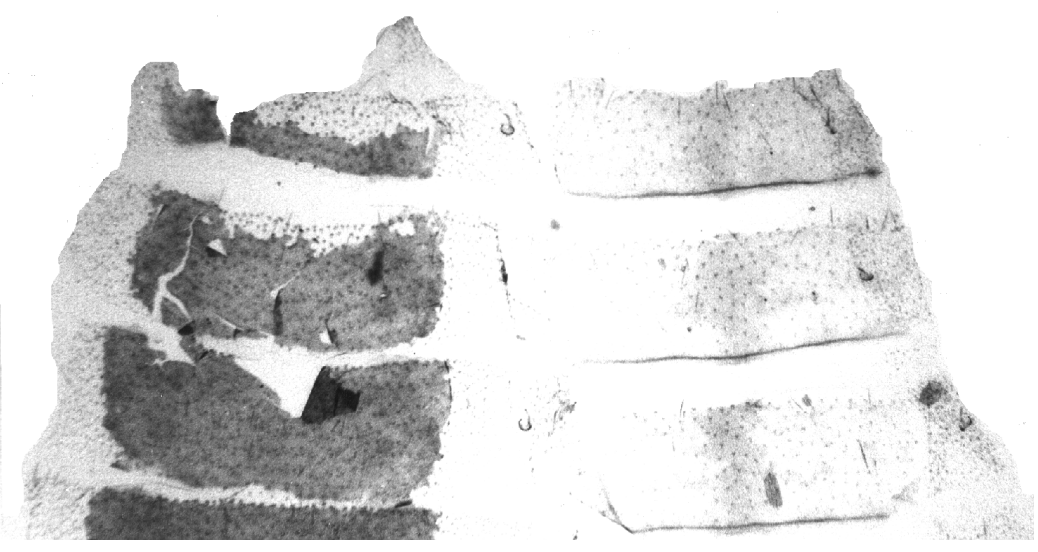

Fig. 14. Tergum VIII (left) and sternum VIII (right) of Scythris spinella sp. $\mathrm{n}$. (holotype).

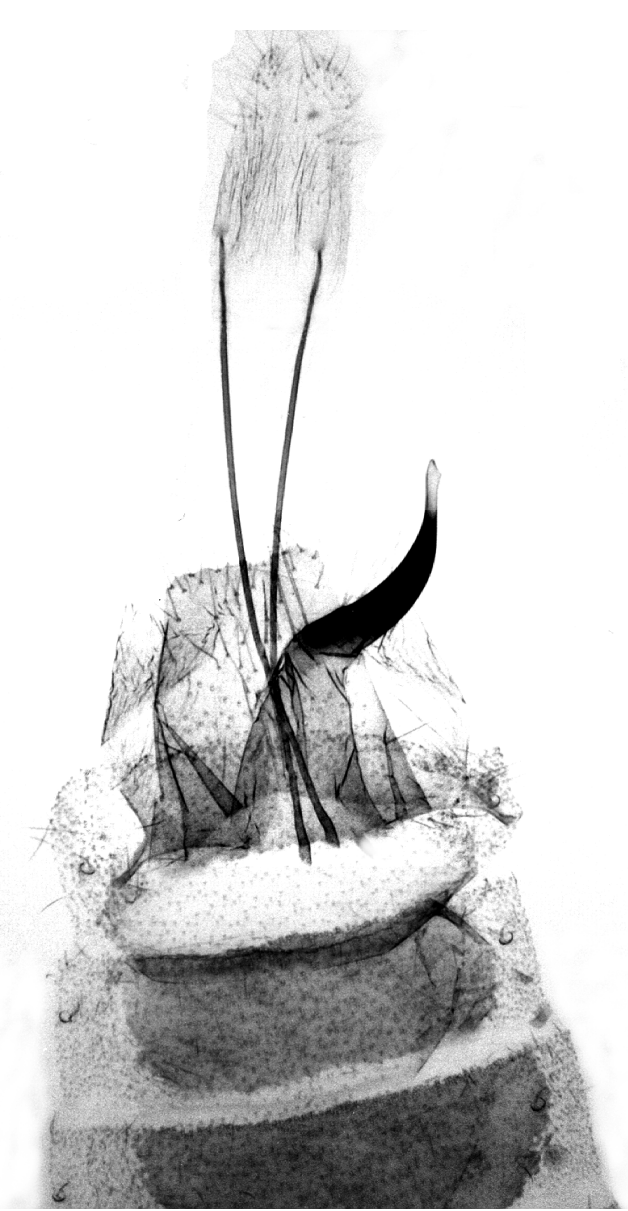

Fig. 15. Female genitalia of Scythris spinella sp. n. (paratype).

Female genitalia (Fig. 15). Sterigma asymmetrical, situated at right, tapered, strongly sclerotized from 0.5 to 0.9 ; basal part almost

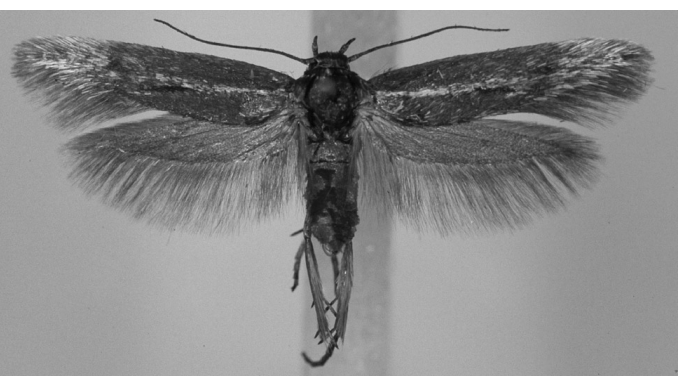

Fig. 16. Imago (holotype) of Scythris tumidella sp. n.

straight; at middle curved $70^{\circ}$, distal half bent, horn-shaped. Segment VIII furrowed. Ventral plate of segment VIII mid-posteriorly large, rectangular, sclerotized and setose. Apophyses posteriores long and slender. Apophyses anteriores short, straight.

Bionomy. The specimens were swept at the end of June on a dry Artemisia-steppe in a grassy spot. The biology is unknown.

Distribution. Russia (Altai Mountains). Only known from the type locality.

Etymology. Lat. spina $=$ thorn. From a thornlike extension in the apex of the right valva in the male genitalia, one of the characteristic details separating the new taxon from a closely related $S$. penicillata.

Remarks. S. spinella sp. n. belongs to the penicillata species-group according to the strange shape of the sterigma in the female genitalia. Also the male genitalia indicate this assignment. $S$. luxatiella seems, however, to share features of both the penicillata and pulicella species-groups, conditions of which are not rare in Scythrididae. 
Fig. 17. Male genitalia of Scythris tumidella sp. $\mathrm{n}$. (paratype).

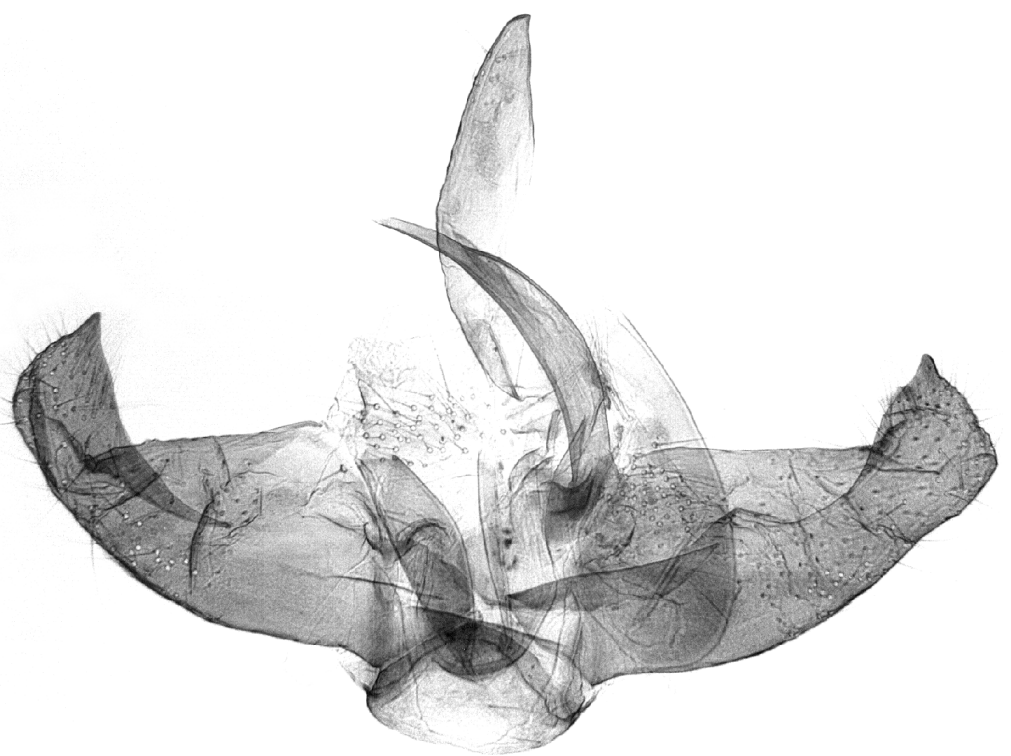

male genitalia.

Description. Wingspan 12-13.5 mm. Head, collar, tegula, thorax and antenna dark brown. Neck tuft, haustellum and scape dark brown, mixed with dirty whitish scales. Labial palp: segment I pale beige, segment II and segment III brown with scattered greyish white scales. Legs brown, femur and ventral surface of tibia mixed with dirty white scales. Abdomen dorsally fuscous, ventrally in male whitish grey, in female pale beige. Forewing dark bronze brown; more or less indistinct white streak in fold from base to midwing; white scales are present also at dorsal margin and more frequently in apical $1 / 4$; indistinct black spot in fold at midwing and another same coloured spot above tornus; amount of white scales varying quite much and in some specimens they are partly replaced by pale brown scales. Hindwing fuscous.

Male genitalia (Figs. 17-18). Uncus thick, ventrally widened, bent, tip pointed. Gnathos absent. Tegumen lateroposteriorly lobate. Aedeagus as long as valva, bent, distally slightly tapered, tip pointed. Valvae slightly asymmetrical, moderately broad, ventrally swollen, at $2 / 3$ twisted $80^{\circ}$; apical portion subtriangular, directed inwards, tip pointed. Tergum VIII subtrapezoidal, anterior margin concave. Sternum VIII subquadrangular; anterior corners rounded, anterior margin medially concave; posterior margin sclerotized, 


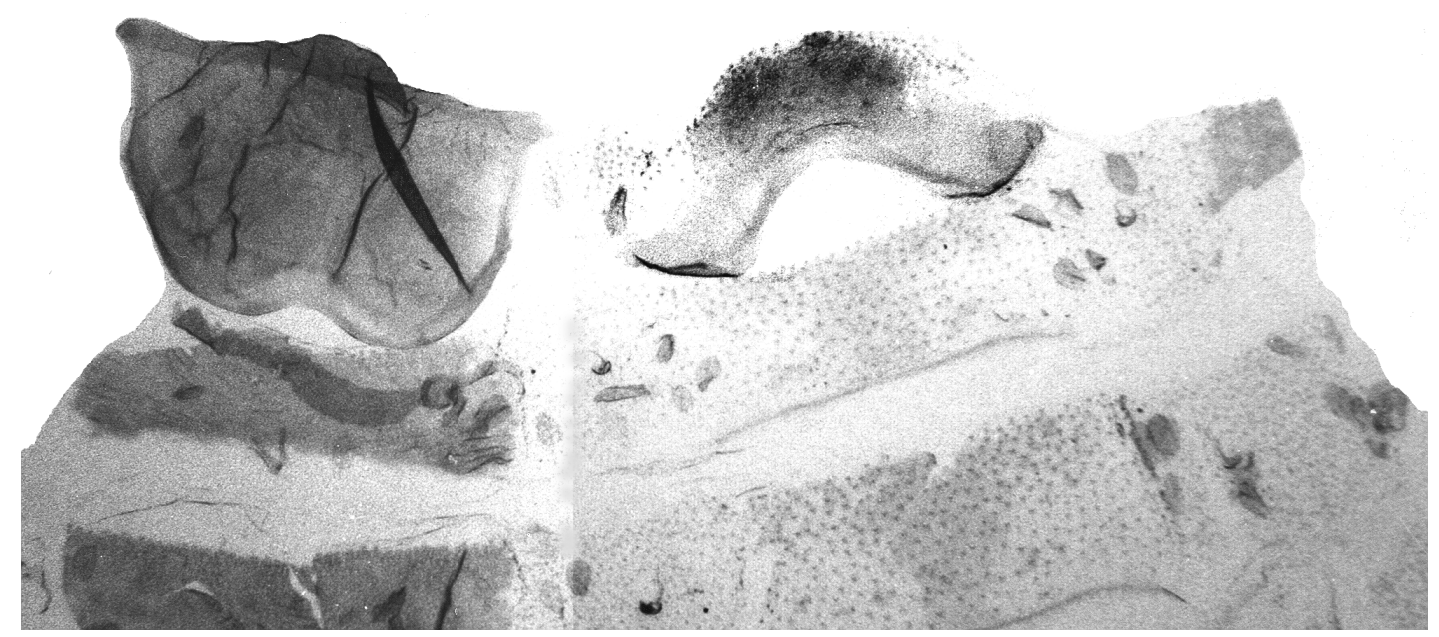

Fig. 18. Tergum VIII (right) and sternum VIII (left) of Scythris tumidella sp. n. (paratype).

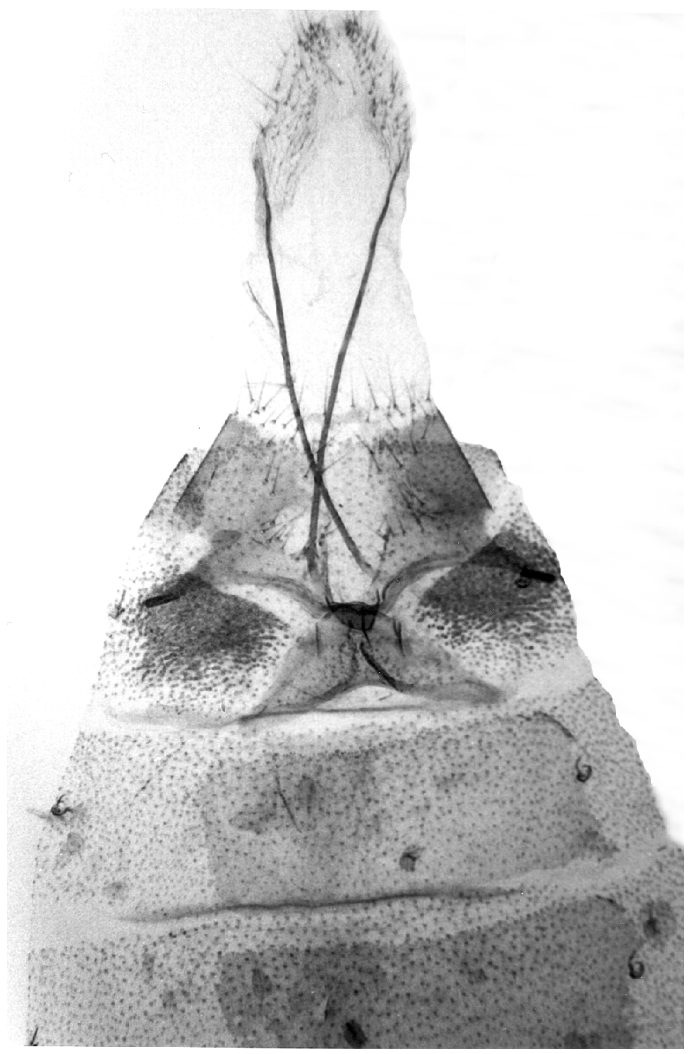

Fig. 19. Female genitalia of Scythris tumidella sp. $\mathrm{n}$. (paratype). straight, medially with rounded extension.

Female genitalia (Fig. 19). Ostium located to left of midline. At midline deep, narrow pouch with sclerotized rims. Between apophyses anteriores sclerotized, transverse, medially incurved band, bordering 'bottom' of pouch. Segment VIII anteromedially with subtriangular structure having elongate anterior corners. Sternum VII rectangular. Apophyses posteriores long and slender. Apophyses anteriores short.

Bionomy. The specimens were collected in the beginning of July by netting on a sandy steppe in a Chuja river shore. The biology is unknown.

Distribution. Russia (Altai Mountains). Only known from the type locality.

Etymology. Lat. tumidus $=$ swollen. From the ventrally swollen valvae in the male genitalia.

Remarks. S. tumidella sp. n. belongs to the aerariella species-group.

\section{Discussion}

Sinev (1993) mentions 8 species of scythridids from SW Altai collected during 1983 by J. Jalava and K. Mikkola. Five of them are absent in our material: S. amphonycella (Geyer, 1832), S. clavella (Zeller, 1855), S. disparella (Tengström, 
1848), S. jalavai Sinev, 1983 and S. pudorinella Möschler, 1866. There are no other published data available about the scythridid fauna of the Altai Mountains. Thus, altogether 21 species of the genus Scythris have been recorded from Altai to date. According to the known distribution ranges of the species, 10 of them are western Palaearctic (range from W Europe to Altai-Baikal region), 6 species are central Palaearctic (Altai-Baikal region), 4 species are widely distributed in central and eastern Palaearctic region (Ural-Altai-Far East) and 1 species is Transpalaearctic. However, the scythridid fauna is poorly known in the Altai region and probably many additional species will be found in the future.

Acknowledgements. We thank Dr. Vladimir Olschwang (Ekaterinburg, Russia) and Mr. Alexander Malozemov (Ekaterinburg, Russia) for organizing the Altai expedition. Our thanks are also due to the following persons for guide services, assistance, company or other kind of help: Mr. Bengt Å. Bengtsson (Färjestaden, Sweden), Mr. Pavel Gorbunov (Ekaterinburg, Russia), Mrs. Elena Nupponen (Espoo, Finland), Mr. Eugenij Shazukevich (Barnaul, Russia). Finally, we thank Mr. Kimmo Silvonen (Espoo, Finland) and Mr. Bo Wikström (Nummela, Finland) for their help in processing the photographs as well as the Lepidopterological Society of Finland for a grant which helped to organize the expedition.

\section{References}

Bengtsson, B. Å. 1997: Scythrididae. — In: Huemer, P., Karsholt, O. \& Lyneborg, L. (eds.), Microlepidoptera of Europe 2: 1-301.

Bengtsson, B. Å. 1997a: Notes on interesting scythridids in the Zoological Museum, Helsinki, Finland (Lepidoptera, Scythrididae). — Entomol. Fennica 8: 89-102.

Bengtsson, B. Å. \& Liška, J. 1996: Notes on Asian scythridids with description of four new species (Lepidoptera, Scythrididae). - Phegea 24: 33-39.

Bengtsson, B. Å. \& Sutter, R. 1996: Scythris felixi sp. n. (Insecta, Lepidoptera: Scythrididae) aus der Mongolei. — Reichenbachia Mus. Tierk. Dresden 31, Nr. 37: 207 208.

Nupponen, K., Bengtsson, B. Å., Kaitila, J.-P., Nupponen, T., Junnilainen, J. \& Olschwang, W. 2000: The scythridid fauna of the southern Ural Mountains, with description of fourteen new species (Lepidoptera: Scythrididae). — Entomol. Fennica 11: 5-34.

Sinev, S. Y. 1993: New and little-known species of the genus Scythris (Lepidoptera, Scythrididae) from Altai. Vestnik zoologii 2: 53-57. [In Russian]. 